\title{
OH defects in quartz in granitic systems doped with spodumene, tourmaline and/or apatite: experimental investigations at 5-20 kbar
}

\author{
C. Frigo $^{1} \cdot$ R. Stalder ${ }^{1}$ C. A. Hauzenberger ${ }^{2}$
}

Received: 6 April 2016 / Accepted: 2 July 2016 / Published online: 29 July 2016

(C) The Author(s) 2016. This article is published with open access at Springerlink.com

\begin{abstract}
The incorporation of $\mathrm{OH}$ defects in quartz as a function of Li content in the bulk system and pressures was investigated. Quartz crystals were grown in water-saturated granitic systems, containing various amounts $\mathrm{Li}, \mathrm{B}$ and $\mathrm{P}$, supplied as accessory phases such as spodumene, tourmaline or apatite in the starting mixtures. High pressure experiments were performed at temperatures between 900 and $1100{ }^{\circ} \mathrm{C}$, and pressures between 5 and 20 kbar with a piston cylinder apparatus, and the synthesized quartz crystals were analyzed by IR spectroscopy, electron microprobe and LA-ICP-MS spectroscopy. All IR absorption spectra revealed absorption features that can be assigned to $\mathrm{AlOH}\left(3313,3379\right.$ and $\left.3431 \mathrm{~cm}^{-1}\right)$ and $(4 \mathrm{H})_{\mathrm{Si}}$ defects $\left(3585 \mathrm{~cm}^{-1}\right)$, whereas quartz grown in the $\mathrm{Li}$ and $\mathrm{B}$ systems exhibited two additional bands related, respectively, to $\mathrm{LiOH}\left(3483 \mathrm{~cm}^{-1}\right)$ and $\mathrm{BOH}$ defects $\left(3596 \mathrm{~cm}^{-1}\right)$. It was further observed that $\mathrm{LiOH}$ incorporation increases with higher spodumene content in the starting material and decreases with pressure, until no $\mathrm{LiOH}$ defects are observed at pressure higher than $15 \mathrm{kbar}$. Specifically, the most pronounced reduction of $\mathrm{LiOH}$ defects occurs in a rather narrow pressure interval (10-15 kbar) close to the high-quartz/ low-quartz transition. However, the link between the transition and the defect incorporation remains unclear. $\mathrm{Li}$ total concentrations always exceed the $\mathrm{Li}$-coupled $\mathrm{LiOH}$ defects, suggesting the simultaneous presence of dry AlLi defects. Results of this study suggest that $\mathrm{LiOH}$ defects are
\end{abstract}

\section{Frigo}

corinne.frigo@uibk.ac.at

1 Institut für Mineralogie und Petrographie, Universität Innsbruck, Innrain 52, 6020 Innsbruck, Austria

2 Institut für Erdwissenschaften, Universität Graz, Universitätsplatz 2, $8010 \mathrm{Graz}$, Austria detectable only in quartz crystals grown from middle and upper crustal sections (such as hydrothermal quartz) and not in quartz from deep roots of orogenic granitoids.

Keywords Quartz · OH defects · IR spectroscopy · Granite $\cdot$ Spodumene

\section{Introduction}

Quartz is one of the most abundant minerals on the Earth's crust. None of the less quartz is a phase that occurs in a broad variety of rocks and therefore crystallizes and equilibrates at different petrogenetic conditions. Quartz may contain different amounts of impurities such as $\mathrm{H}, \mathrm{Li}, \mathrm{B}, \mathrm{Na}$, $\mathrm{Al}, \mathrm{P}, \mathrm{K}, \mathrm{Ti}, \mathrm{Fe}$, and $\mathrm{Ge}$ depending on the formation conditions at different geological environments (e.g., different temperatures, pressures and chemical environments). Some of these trace elements (i.e., $\mathrm{Al}$ and $\mathrm{Ti}$ ) have been successfully applied as geothermometers (Dennen et al. 1970; Wark and Watson 2006; Thomas et al. 2010; Huang and Audétat 2012).

Methodologically, it is possible to determine the quartz grains provenience (1) by means of their luminescence caused by trace metal defects in cathodoluminescence (CL) spectroscopy (Zinkernagel 1978; Matter and Ramseyer 1985; Richter et al. 2003); (2) by chemical analysis of their trace content of impurity metals applied with the electron microprobe or LA-ICP-MS (Müller et al. 2003; Müller and Koch-Müller 2009), or (3) by their inventory of hydrous defects that charge compensate metal impurities involving mono-, tri- or pentavalent cations. In this respect, many studies focused on the determination of species and concentration of hydrous defects in quartz by Fourier transform infrared (FTIR) spectroscopic analyses. 
Trace elements and hydrous defects are often incorporated in quartz by coupled substitutions of one silicon cation by trivalent (e.g., $\mathrm{Al}^{3+}, \mathrm{B}^{3+}$ and $\mathrm{Fe}^{3+}$ ) and monovalent (e.g., $\mathrm{H}^{+}, \mathrm{Li}^{+}, \mathrm{K}^{+}$and $\mathrm{Na}^{+}$), or trivalent and pentavalent (e.g., $\left.\mathrm{P}^{5+}\right)$ cations. Substitutions such as $\mathrm{Si}^{4+}=\mathrm{Al}^{3+}+\mathrm{H}^{+}$ cause $\mathrm{AlOH}$ defects, which are characterized by three absorption bands at 3313, 3379 and $3431 \mathrm{~cm}^{-1}$ in the infrared range (Kats 1962; Bambauer 1963; Aines and Rossman 1984; Stalder and Konzett 2012). Other coupled substitutions involving the incorporation of protons in the quartz structure such as $\mathrm{Si}^{4+}=\mathrm{B}^{3+}+\mathrm{H}^{+}$and $\mathrm{Si}^{4+}=4 \mathrm{H}^{+}$ generate the BOH (Müller and Koch-Müller 2009) and the $(4 \mathrm{H})_{\mathrm{Si}}$ hydrogarnet defect (Paterson 1986; Stalder and Konzett 2012), characterized by the bands at 3596 and $3585 \mathrm{~cm}^{-1}$, respectively. The occurrence of the interstitial hydrous defects such as $\mathrm{LiOH}$ causes the absorption band at $3483 \mathrm{~cm}^{-1}$ (Kats 1962; Aines and Rossman 1984; Baron et al. 2015).

The intensity of these absorption bands depend on the prevailing conditions during crystallization or annealing and may be used to define the provenance of an individual quartz grain. For example, the hydrogarnet defect is a common point defect in synthetic quartz crystallized in a chemically pure system (Chakraborty and Lehmann 1976; Paterson 1986; Rovetta 1989). Concentrations of hydrogarnet in quartz from granitic systems are correlated to pressure (Stalder and Konzett 2012) and therefore may be used to distinguish between low- and high-pressure origins, while the concentration of $\mathrm{AlOH}$ defects is both temperature and pressure dependent, and cannot give additional information about the genesis conditions. In contrast, the concentration of $\mathrm{BOH}$ defects is not pressure dependent (Baron et al. 2015). Generally, quartz crystals of magmatic origin are mainly characterized by $\mathrm{AlOH}$ defects and therefore by higher incorporation of $\mathrm{H}^{+}$with respect to other rocks (Müller and Koch-Müller 2009; Stalder and Neuser 2013). In addition, rocks of pegmatitic origins are enriched in $\mathrm{LiOH}$ and $\mathrm{BOH}$ defects (Stalder and Neuser 2013). The major purpose of this work is a more detailed study to assess $\mathrm{LiOH}$ defects in the quartz structure depending on pressure and chemical system, with the aim to use this feature as petrological indicator. To achieve this goal, several high-pressure experiments were performed on a granite-spodumene system at pressures ranging from 5 to $20 \mathrm{kbar}$, which represents the pressure conditions from upper to lower crust in collision zones. Furthermore, few additional experiments on granite containing tourmaline and/or apatite were performed, in order to evaluate whether the charge neutrality equation $\mathrm{H}^{+}+\mathrm{A}^{+}+\mathrm{P}^{5+}=\mathrm{M}^{3+}+\mathrm{B}^{3+}$, where $\mathrm{A}=$ alkali and $M=$ metal ions (Müller and Koch-Müller 2009; Baron et al. 2015), is achieved.

\section{Experimental and analytical methods}

\section{Starting materials}

Quartz crystals were grown in the following systems: (1) quartz-granite-spodumene-water, (2) quartz-granite-tourmaline-water, (3) quartz-granite-apatite-water, (4) quartzgranite-spodumene-apatite-water and (5) quartz-granitetourmaline-apatite-water. All starting materials consisted of synthetic quartz (Alfa Aesar $99.995 \%$ purity) and natural granite from Sardinia/Italy, which was derived from the institute rock collection $\left(68.90 \mathrm{wt} \% \mathrm{SiO}_{2}, 14.87 \mathrm{wt} \%\right.$ $\mathrm{Al}_{2} \mathrm{O}_{3}, 6.35$ wt $\% \mathrm{~K}_{2} \mathrm{O}, 3.05 \mathrm{wt} \% \mathrm{Na}_{2} \mathrm{O}, 2.51 \mathrm{wt} \% \mathrm{Fe}_{2} \mathrm{O}_{3}$, $1.56 \mathrm{wt} \% \mathrm{CaO}, 0.50 \mathrm{MgO}, 0.27 \mathrm{wt} \% \mathrm{TiO}_{2}, 0.08 \mathrm{wt} \% \mathrm{MnO}$, $0.04 \mathrm{wt} \% \mathrm{P}_{2} \mathrm{O}_{5}$ ). Both synthetic quartz and natural granite powders were mixed in proportion of $1: 1$, partially molten in a platinum crucible at $1100{ }^{\circ} \mathrm{C}$ for four hours, in order to promote the homogenization of the granitic components, and rapidly quenched to glass. The resulting glass + quartz mixture was successively ground to powder and finally mixed with different amounts of powdered spodumene, tourmaline and/or apatite, for doping the system with $\mathrm{Li}, \mathrm{B}$, and $\mathrm{P}$, respectively. Details concerning the starting material are reported in Table 1.

\section{High pressure experiments}

Each solid mixture was filled together with 12-25 wt $\%$ water in Pt capsules with an outer (inner) diameter of 4.0 (3.6) $\mathrm{mm}$. The capsule was then closed, welded shut, weighted and checked for leakage in an oven at $120{ }^{\circ} \mathrm{C}$. The capsule was finally inserted in a BN sleeve, which produces an oxygen fugacity between $\mathrm{CoCoO}$ and $\mathrm{WM}$ (Truckenbrodt et al. 1997). All syntheses were performed in an end-loaded piston cylinder press using a $\mathrm{NaCl}$ assembly with graphite furnace. For experiments with pressures from 5 to 7.5 kbar a 22-mm assembly in combination with Pyrex sleeve was used, while a half-inch $\mathrm{NaCl}$ assembly was used for experiments at pressures from 10 to $20 \mathrm{kbar}$. Temperatures were monitored by using $\mathrm{Ni}-\mathrm{CrNi}$ thermocouples. In order to promote crystal growth, the temperature was initially raised to $1100-1000{ }^{\circ} \mathrm{C}$ (Table 1 ), followed by a ramp down $900{ }^{\circ} \mathrm{C}$ at a cooling rate of $20{ }^{\circ} \mathrm{C} / \mathrm{h}$. Temperatures were hold for $50-120 \mathrm{~h}$ (Table 1), and runs were terminated by shutting off the power supply.

The recovered capsules were then weighted, pierced, dried and weighted again, for verifying any fluid loss and quantifying the amount of water retained in the run products. If the products were fluid-saturated, it was possible to measure the fluid's $\mathrm{pH}$, by $\mathrm{pH}$ indication paper, after piercing the capsule. The $\mathrm{pH}$ of the excess fluid was neutral or very weak alkalic ( $\mathrm{pH}$ 6-7) for all the runs. Most 
Table 1 Experimental conditions and starting material

\begin{tabular}{llllllllllll}
\hline Run \# & Assembly $(\mathrm{mm})$ & Capsule $(\mathrm{mm})$ & Granite $(\mathrm{mg})$ & Qz $(\mathrm{mg})$ & Spd $(\mathrm{mg})$ & Tur $(\mathrm{mg})$ & Ap $(\mathrm{mg})$ & Water $(\mathrm{mg})$ & $P(\mathrm{kbar})$ & $T\left({ }^{\circ} \mathrm{C}\right)$ & $t(\mathrm{~h})$ \\
\hline E16 & NaCl-Pyrex 22 & Pt 3.0 & 15.30 & 15.30 & 0.61 & 0.00 & 0.00 & 5.50 & 5 & 900 & 50 \\
E33 & NaCl-Pyrex 22 & Pt 4.0 & 14.45 & 14.46 & 0.59 & 0.00 & 0.00 & 1.40 & 5 & 900 & 62 \\
E24 & NaCl-Pyrex 22 & Pt 4.0 & 24.95 & 24.95 & 1.10 & 0.00 & 0.00 & 15.40 & 7.5 & $1050-900$ & 96 \\
E27 & NaCl-Pyrex 22 & Pt 4.0 & 24.75 & 24.74 & 1.01 & 0.00 & 0.00 & 9.80 & 7.5 & $1100-900$ & 98 \\
E17 & NaCl 12.7 & Pt 4.0 & 24.66 & 24.65 & 1.09 & 0.00 & 0.00 & 8.00 & 10 & $1000-900$ & 96 \\
E20 & NaCl 12.7 & Pt 4.0 & 27.05 & 27.05 & 0.00 & 0.00 & 0.00 & 15.20 & 10 & $1000-900$ & 119 \\
E21 & NaCl 12.7 & Pt 4.0 & 23.80 & 23.80 & 5.60 & 0.00 & 0.00 & 17.00 & 10 & $1000-900$ & 53 \\
E22 & NaCl 12.7 & Pt 4.0 & 23.75 & 23.75 & 0.00 & 0.00 & 2.50 & 15.30 & 10 & $1000-900$ & 53 \\
E23 & NaCl 12.7 & Pt 4.0 & 24.13 & 24.13 & 0.00 & 2.54 & 0.00 & 15.40 & 10 & $1000-900$ & 77 \\
E26 & NaCl 12.7 & Pt 4.0 & 20.04 & 20.03 & 9.93 & 0.00 & 0.00 & 17.00 & 10 & $1000-900$ & 69 \\
E29 & NaCl 12.7 & Pt 4.0 & 23.04 & 23.04 & 0.00 & 2.46 & 1.07 & 16.20 & 10 & $1000-900$ & 71 \\
E30 & NaCl 12.7 & Pt 4.0 & 24.68 & 24.68 & 5.74 & 0.00 & 2.93 & 18.60 & 10 & $1000-900$ & 95 \\
E19 & NaCl 12.7 & Pt 4.0 & 26.47 & 26.46 & 1.17 & 0.00 & 0.00 & 14.90 & 12.5 & $1030-900$ & 72 \\
E18 & NaCl 12.7 & Pt 4.0 & 25.19 & 25.19 & 1.11 & 0.00 & 0.00 & 18.00 & 15 & $1050-900$ & 68 \\
E14 & NaCl 12.7 & Pt 4.0 & 24.85 & 24.85 & 0.99 & 0.00 & 0.00 & 16.66 & 20 & $1050-900$ & 95 \\
\hline
\end{tabular}

$Q z$ quartz, $S p d$ spodumene, Tur tourmaline, $A p$ apatite

of the run products consisted exclusively of quartz crystals and quench material. In some runs, also spodumene (run: E30) and apatite crystals (runs: E29 and E30) could be observed (Fig. 1c), but may have also been present in very small proportions in other runs. It was also observed that quartz's crystal size changes in function of pressures and bulk composition of the starting material. Quartz crystals were then individually handpicked, mounted in thermoplastic resin and oriented parallel to the $\mathrm{c}$ axis with a polarizing microscope. Birefringence values of $\Delta n=0.009$ in the orthoscopic view and "flash figures" in the conoscopic view confirmed a successful orientation of the quartz crystal. A $\lambda$-plate compensator was employed to determine the direction of the ordinary $\left(n_{\mathrm{o}}\right)$ and extraordinary $\left(n_{\mathrm{e}}\right)$ refractive indices, an essential prerequisite to perform polarized measurements with FTIR spectroscopy. Oriented crystals were manually ground, polished on both sides and finally removed from the resin by dissolution in acetone. Crystal thicknesses were measured with a mechanical Mitutoyo micrometer with an accuracy of $\pm 2 \mu \mathrm{m}$. Characteristics of the prepared crystals including water concentrations are reported in Table 2.

\section{FTIR spectroscopy}

Mid-infrared spectra were recorded at room temperature in transmission mode by using a Bruker Vertex 70 FTIR spectrometer coupled to a Hyperion 3000 microscope, a nitrogen-cooled MCTD316-025 (mercury cadmium telluride) detector, a globar light source, a $\mathrm{KBr}$ beamsplitter and a wire grid polarizer. Background and sample measurements were taken by averaging 32-300 scans, depending on the measured area that varied from $100 \times 100$ to $40 \times 40 \mu^{2}$. Polarized measurements were taken along the ordinary $\left(n_{\mathrm{o}}\right)$ and extraordinary $\left(n_{\mathrm{e}}\right)$ refractive indexes on the same spot by turning the polarizers' direction by $90^{\circ}$. All IR bands related to $\mathrm{OH}$ defects are strongly polarized in the direction parallel to $\mathrm{n}_{\mathrm{o}}$ and exhibit almost no absorbance in the direction parallel to $n_{\mathrm{e}}$. Fluid/melt inclusions exhibit weak and broad absorption features in the $\mathrm{OH}$ range. Because of their isotropic behavior, the contribution of molecular water trapped as fluid micro-inclusions or in quench hydrous melt inclusions was eliminated by subtracting the $n_{e}$ component from the $\mathrm{n}_{\mathrm{o}}$ component of the $\mathrm{OH}$ absorption pattern according to the procedure described by Stalder and Konzett (2012). An additional correction described from Baron et al. (2015) was required for spectra containing $\mathrm{BOH}$ absorption bands, since the B-related $\mathrm{OH}$ defects exhibit a significant component for $E \| n_{\mathrm{e}}$. Water concentrations were calculated by integrating the polarized background-corrected IR spectra (normalized to thickness) across the region of absorption due to $\mathrm{OH}$ dipole vibrations $\left(3700-3200 \mathrm{~cm}^{-1}\right)$. The integrated extinction coefficients from mineral-specific (Aines et al. 1984; Thomas et al. 2009) and general wavelength-specific (Libowitzky and Rossman 1997) calibrations were used. All three calibrations yield for most samples results in excellent agreement to each other. Significant deviations only occur for spectra with strong absorptions in the high wavenumber range (Stalder and Konzett 2012; Baron et al. 2015), which are not relevant for the present study. 


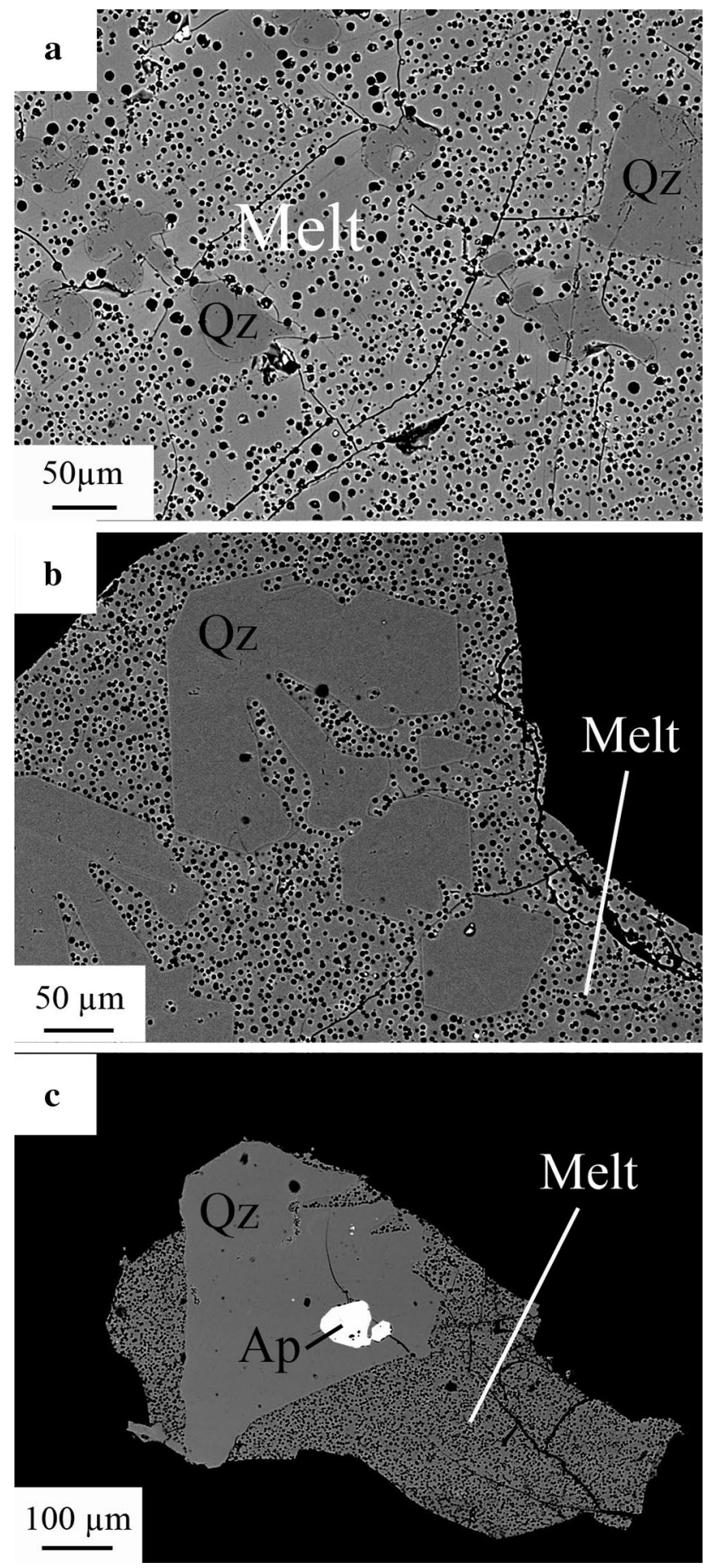

Fig. 1 BSE image of quartz (Qz) crystals in water-saturated melt from run E17 (a) and E20 (b) and euhedral apatite (Ap) crystals from runs E29 (c)

\section{Electron microprobe}

Textures from run products were inspected under a JEOL JXA-8100 electron microprobe (Fig. 1), and major and minor element chemistry of quartz crystals and quenched melt were determined using $15 \mathrm{kV}$ acceleration voltage. Concerning the beam current different analytical conditions were used depending on the measured material, $50 \mathrm{nA}$ beam current on quartz for acquisition of the $\mathrm{Al}-\mathrm{K} \alpha$ line using a raster size of $12 \times 9 \mu \mathrm{m}$, and $5 \mathrm{nA}$ beam on quenched melt using a $6 \times 8 \mu \mathrm{m}$ raster size. As standards, the following minerals were used: $\mathrm{Si}$ : quartz, $\mathrm{Al}$ : corundum, K: orthoclase, Na: jadeite, P: apatite, Fe: almandine, $\mathrm{Mg}: \mathrm{MgO}, \mathrm{Ca}$ : diopside, Ti: rutile, $\mathrm{Mn}$ : tephroite.

\section{LA-ICP-MS}

Trace element concentrations in quartz grains were analyzed by LA-ICP-MS (laser ablation unit: ESI NWR 193; ICP-MS: Agilent 7500ce) at the Central Lab for Water, Minerals and Rocks, NAWI Graz, Karl-Franzens-University of Graz and Graz University of Technology). The material was ablated by using a $193 \mathrm{~nm}$ laser pulsed at $10 \mathrm{~Hz}, 50 \mu \mathrm{m}$ spot size with energy of $\sim 7.5 \mathrm{~J} \mathrm{~cm}^{-2}$ and $11 \mathrm{~Hz}$ for measurements of $35 \mu \mathrm{m}$ spot size, with energy of $\sim 8.5 \mathrm{~J} \mathrm{~cm}^{-2}$. Helium was used as carrier gas at $\sim 0.61 / \mathrm{min}$ flow, and data were acquired in time-resolved mode. For each analysis a $30 \mathrm{~s}$ gas blank was obtained for background correction, followed by $60 \mathrm{~s}$ of active laser and a wash out time of $45 \mathrm{~s}$. NIST612 glass was used for standardization and drift correction, while NIST614 and SL-1 (G-Probe proficiency program, www.geoanalyst.org) were analyzed as unknowns to monitor the accuracy of the measurements. Both standards could be reproduced within $\pm 10 \%$ of the recommended values. Data reduction for quartz crystal analyses was performed using the software Glitter with silicon as internal standard, while element concentrations in the quench material was determined successively using the software SILLS (Guillong et al. 2008), which was gently granted from Dr. Markus Wälle from ETH, Zürich. For NIST612, the concentration values reported by Jochum et al. (2011) were used.

\section{Results}

\section{IR band assignment and determination of water content as $\mathrm{OH}$ defects}

All the IR absorption spectra revealed at least two specific absorption features, in particular a dominating triplet at 3313,3379 and $3431 \mathrm{~cm}^{-1}$, and a much weaker band at $3585 \mathrm{~cm}^{-1}$, which can be assigned to $\mathrm{AlOH}$ defects (Kats 1961, 1962; Bambauer 1963) and hydrogarnet $(4 \mathrm{H})_{\mathrm{Si}}$ defects, respectively. In addition, quartz crystals from the spodumene-bearing system show another band at $3483 \mathrm{~cm}^{-1}$ at pressures $\leq 10 \mathrm{kbar}$. This band corresponds to the $\mathrm{LiOH}$ defects and its absorbance is negatively correlated to pressure (Fig. 2). Quartz crystals grown in the 
Table 2 IR measurements

\begin{tabular}{|c|c|c|c|c|c|c|c|}
\hline \multirow[t]{2}{*}{ Sample \# } & \multirow[t]{2}{*}{$P($ kbar $)$} & \multirow[t]{2}{*}{ Thickness $(\mu \mathrm{m})$} & \multicolumn{3}{|c|}{ Water concentration (ppm) } & \multicolumn{2}{|c|}{$\begin{array}{l}\text { Water as } \mathrm{Li}-\mathrm{OH} \\
(\mathrm{ppm})\end{array}$} \\
\hline & & & $\mathrm{T}(09)$ & L\&R (97) & A (84) & $\mathrm{T}(09)$ & L\&R (97) \\
\hline E16qz1 & 5 & 102 & 61.2 & 62.9 & 63.2 & 7.8 & 10.4 \\
\hline E24qz1 & 7.5 & 83 & 72.1 & 74.5 & 74.4 & 6.4 & 8.5 \\
\hline E24qz2 & 7.5 & 106 & 66.7 & 69.7 & 68.8 & 3.0 & 4.0 \\
\hline E24qz3 & 7.5 & 123 & 79.0 & 81.1 & 81.5 & 3.6 & 4.8 \\
\hline E24qz4 & 7.5 & 137 & 45.4 & 48.5 & 46.9 & 3.6 & 4.8 \\
\hline E24qz5 & 7.5 & 150 & 84.2 & 86.0 & 86.8 & 3.8 & 5.1 \\
\hline E27qz1 & 7.5 & 153 & 61.6 & 64.6 & 63.6 & 3.2 & 4.2 \\
\hline E27qz2 & 7.5 & 150 & 54.7 & 57.0 & 56.4 & 2.5 & 3.3 \\
\hline E27qz3 & 7.5 & 102 & 73.4 & 79.9 & 75.6 & 4.1 & 5.5 \\
\hline E27qz4 & 7.5 & 97 & 83.1 & 81.9 & 85.7 & 5.0 & 6.7 \\
\hline E27qz6 & 7.5 & 57 & 49.2 & 52.4 & 50.8 & 1.8 & 2.4 \\
\hline E17qz1 & 10 & 69 & 51.4 & 52.2 & 53.2 & 1.4 & 1.9 \\
\hline E17qz3 & 10 & 90 & 40.6 & 43.5 & 41.9 & 0.8 & 1.1 \\
\hline E17qz4 & 10 & 92 & 38.1 & 40.4 & 39.4 & 1.3 & 1.7 \\
\hline E17qz5 & 10 & 92 & 55.4 & 58.0 & 57.2 & 2.5 & 3.3 \\
\hline E17qz6 & 10 & 96 & 40.0 & 41.6 & 41.3 & 1.6 & 2.1 \\
\hline E17qz7 & 10 & 107 & 63.0 & 65.0 & 65.0 & 2.0 & 2.7 \\
\hline E20qz1 & 10 & 100 & 47.5 & 48.6 & 49.0 & 0.0 & 0.0 \\
\hline E20qz2_1 & 10 & 144 & 32.3 & 34.5 & 33.4 & 0.0 & 0.0 \\
\hline E20qz2_2 & 10 & 144 & 36.8 & 34.3 & 37.9 & 0.0 & 0.0 \\
\hline E20qz2_3 & 10 & 144 & 44.6 & 46.4 & 46.0 & 0.0 & 0.0 \\
\hline E20qz3 & 10 & 80 & 39.2 & 41.0 & 40.5 & 0.0 & 0.0 \\
\hline E21qz1 & 10 & 127 & 35.2 & 37.1 & 36.4 & 3.7 & 4.9 \\
\hline E21qz2 & 10 & 123 & 52.3 & 55.1 & 53.9 & 4.6 & 6.1 \\
\hline E21qz3 & 10 & 91 & 39.4 & 41.3 & 40.9 & 3.1 & 4.2 \\
\hline E22qz1 & 10 & 115 & 32.8 & 34.8 & 33.9 & 0.0 & 0.0 \\
\hline E22qz2 & 10 & 54 & 47.3 & 49.3 & 48.8 & 0.0 & 0.0 \\
\hline E22qz3 & 10 & 75 & 61.5 & 63.8 & 63.5 & 0.0 & 0.0 \\
\hline E22qz4 & 10 & 79 & 85.1 & 86.0 & 87.8 & 0.0 & 0.0 \\
\hline E22qz5 & 10 & 88 & 37.8 & 38.4 & 39.0 & 0.0 & 0.0 \\
\hline E23qz1 & 10 & 139 & 68.7 & 72.6 & 71.0 & 0.0 & 0.0 \\
\hline E23qz2 & 10 & 128 & 136.4 & 135.7 & 140.7 & 0.0 & 0.0 \\
\hline E23qz3 & 10 & 109 & 119.6 & 127.6 & 123.3 & 0.0 & 0.0 \\
\hline E23qz4 & 10 & 96 & 150.3 & 156.9 & 155.0 & 0.0 & 0.0 \\
\hline E23qz5 & 10 & 84 & 126.0 & 131.1 & 130.0 & 0.0 & 0.0 \\
\hline E23qz6 & 10 & 80 & 90.6 & 93.9 & 93.5 & 0.0 & 0.0 \\
\hline E23qz7 & 10 & 72 & 81.5 & 85.0 & 84.1 & 0.0 & 0.0 \\
\hline E26qz1 & 10 & 86 & 30.4 & 32.5 & 31.3 & 4.6 & 6.1 \\
\hline E26qz2 & 10 & 71 & 36.3 & 40.1 & 37.6 & 6.9 & 9.2 \\
\hline E29qz1 & 10 & 97 & 66.5 & 69.1 & 68.6 & 0.0 & 0.0 \\
\hline E29qz2 & 10 & 92 & 83.4 & 86.7 & 86.0 & 0.0 & 0.0 \\
\hline E30qz2 & 10 & 81 & 44.1 & 46.3 & 45.5 & 2.7 & 3.6 \\
\hline E30qz3 & 10 & 57 & 45.1 & 48.0 & 46.5 & 2.6 & 3.5 \\
\hline E19qz1 & 12.5 & 104 & 29.2 & 30.9 & 30.1 & 0.0 & 0.0 \\
\hline E19qz2 & 12.5 & 117 & 41.7 & 43.0 & 43.1 & 0.0 & 0.0 \\
\hline E19qz4 & 12.5 & 90 & 49.3 & 51.6 & 50.9 & 0.0 & 0.0 \\
\hline E19qz5 & 12.5 & 118 & 43.7 & 45.8 & 45.1 & 0.0 & 0.0 \\
\hline
\end{tabular}


Table 2 continued

\begin{tabular}{|c|c|c|c|c|c|c|c|}
\hline \multirow[t]{2}{*}{ Sample \# } & \multirow[t]{2}{*}{$P($ kbar $)$} & \multirow[t]{2}{*}{ Thickness $(\mu \mathrm{m})$} & \multicolumn{3}{|c|}{ Water concentration (ppm) } & \multicolumn{2}{|c|}{$\begin{array}{l}\text { Water as } \mathrm{Li}-\mathrm{OH} \\
(\mathrm{ppm})\end{array}$} \\
\hline & & & $\mathrm{T}(09)$ & L\&R (97) & $\mathrm{A}(84)$ & $\mathrm{T}(09)$ & L\&R (97) \\
\hline$\overline{\text { E18qz1 }}$ & 15 & 98 & 42.4 & 44.6 & 43.7 & 0.0 & 0.0 \\
\hline E18qz3 & 15 & 97 & 29.6 & 31.9 & 30.5 & 0.0 & 0.0 \\
\hline E18qz4 & 15 & 74 & 39.9 & 43.0 & 41.1 & 0.0 & 0.0 \\
\hline E14qz1 & 20 & 155 & 34.6 & 36.8 & 35.7 & 0.0 & 0.0 \\
\hline E14qz2 & 20 & 105 & 41.4 & 44.0 & 42.7 & 0.0 & 0.0 \\
\hline E14qz3 & 20 & 104 & 43.9 & 47.0 & 45.3 & 0.0 & 0.0 \\
\hline E14qz4 & 20 & 145 & 27.2 & 28.8 & 28.5 & 0.0 & 0.0 \\
\hline
\end{tabular}

$\mathrm{T}(09)=$ according to calibration of Thomas et al. (2009)

L\&R (97) = according to calibration of Libowitzky and Rossman (1997)

A (84) = according to calibration of Aines et al. (1984)

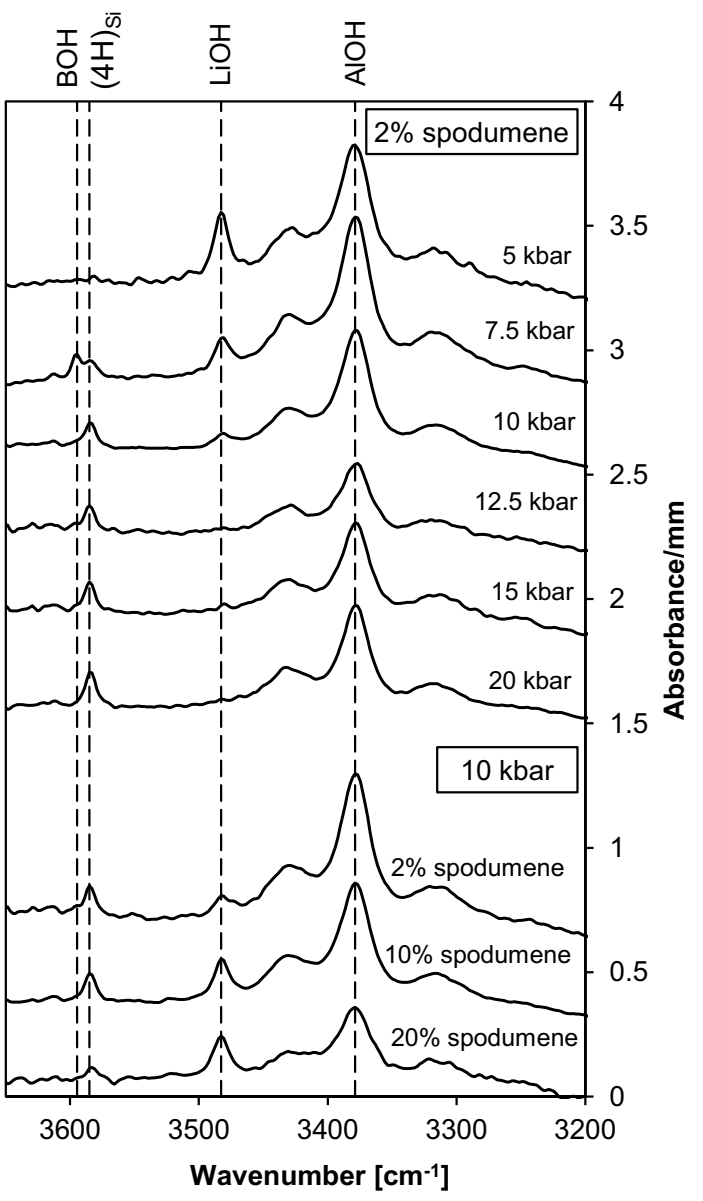

Fig. 2 IR spectra from quartz grown at different pressures (all with $2 \%$ spodumene in the system) and different spodumene content in the system (all at $10 \mathrm{kbar}$ )

tourmaline-bearing systems show an additional band at $3596 \mathrm{~cm}^{-1}$ that can be assigned to BOH defects (Müller and Koch-Müller 2009). The existence of a further band at $3469 \mathrm{~cm}^{-1}$ is not as clear. If this band is considered real, it

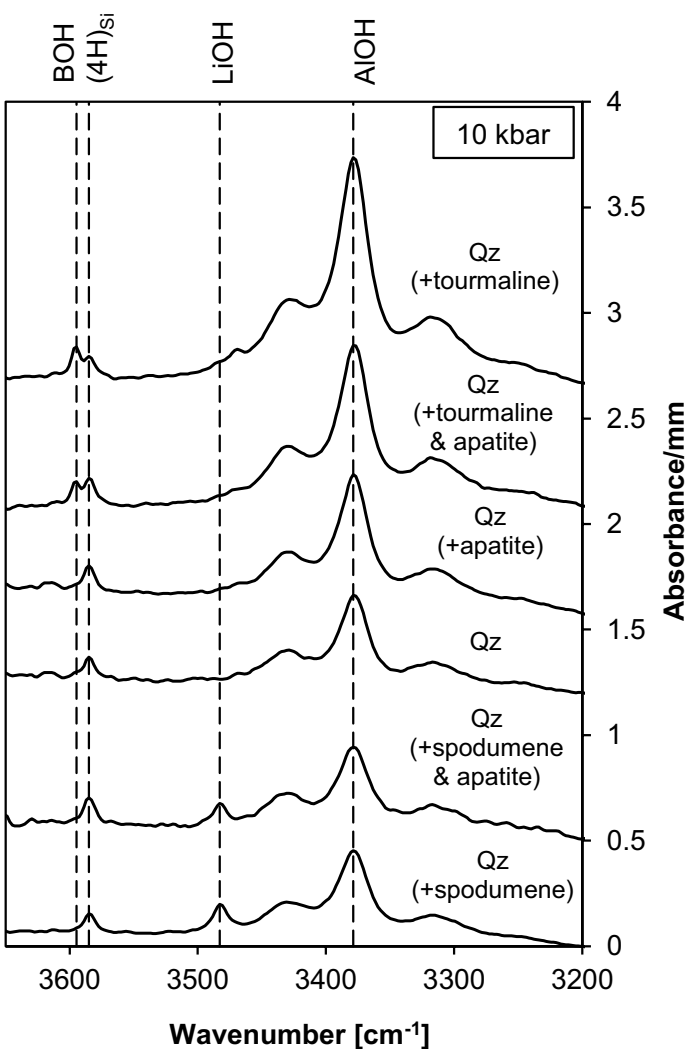

Fig. 3 IR spectra from quartz synthesized at $10 \mathrm{kbar}$ in different bulk compositions containing different amounts of apatite, tourmaline and spodumene

may represent another Li-related defect (Kats 1961). Crystal's grown in systems containing apatite did not show any additional bands; however, it is observed that the presence of apatite component in the bulk system show a weak negative effect on the intensities of $\mathrm{OH}$ bands related to trivalent cations, e.g., the B-related band at $3596 \mathrm{~cm}^{-1}$ and the Alrelated band at $3379 \mathrm{~cm}^{-1}$ (Fig. 3). 


\section{Influence of chemical and physical parameters on $\mathrm{OH}$ incorporation}

At $10 \mathrm{kbar}$, the $\mathrm{LiOH}$ concentration is correlated to the spodumene content in the starting material (Fig. 4). As this trend is followed up to high spodumene contents (i.e., $20 \mathrm{wt} \%$ in the bulk system), no evidence for saturation with respect to $\mathrm{LiOH}$ in quartz is apparent. At $5 \mathrm{kbar}$, very high $\mathrm{LiOH}$ concentrations in quartz are already observed at much lower spodumene contents (i.e., $2 \mathrm{wt} \%$ ) in the system, suggesting that the saturation is reached at lower concentration levels and spodumene is less dissolved in the melt at lower pressure. Another experiment performed at $5 \mathrm{kbar}$ with higher concentrations of spodumene in the bulk system would be critical to understand whether LiOH saturation already occurred. Such an experiment was performed (E33, Table 1). However, no crystals (neither spodumene nor quartz) could be observed in the run product neither under petrographic microscope, nor by XRD. Either the system was super-liquidus or nucleation was too sluggish to form crystals.

As far as the pressure effect on the $\mathrm{OH}$ incorporation in quartz is concerned, crystals grown from the starting material containing $2 \%$ spodumene show not a clear trend, but a jump for the $\mathrm{AlOH}$ defects from ca. $60 \mathrm{wt}$ ppm water at 5 kbar to a constant value of ca. 40 wt ppm water starting from $12.5 \mathrm{kbar}$ (Fig. 5). This result slightly modifies previous experimental results on quartz in granitic systems, where a negative relation between $\mathrm{AlOH}$ concentrations and pressure was observed (Stalder and Konzett 2012; Baron et al. 2015).

Similar to $\mathrm{AlOH}$, the $\mathrm{LiOH}$ content in quartz shows an evident negative correlation with pressures, and-at

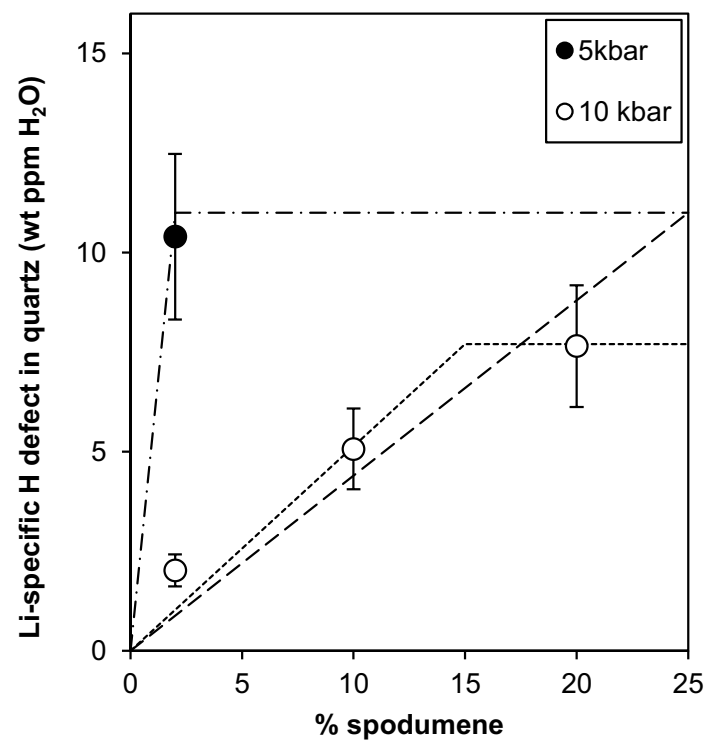

Fig. $4 \mathrm{OH}$ content in quartz as $\mathrm{LiOH}$ defects against the spodumene content in the starting material (as wt ppm water)
2 wt\% spodumene in the starting material-basically drops to zero at $12.5 \mathrm{kbar}$ (Fig. 6). If we assume that similar trends occur at higher spodumene contents, $\mathrm{LiOH}$ defects could be present up to $15 \mathrm{kbar}$, but would

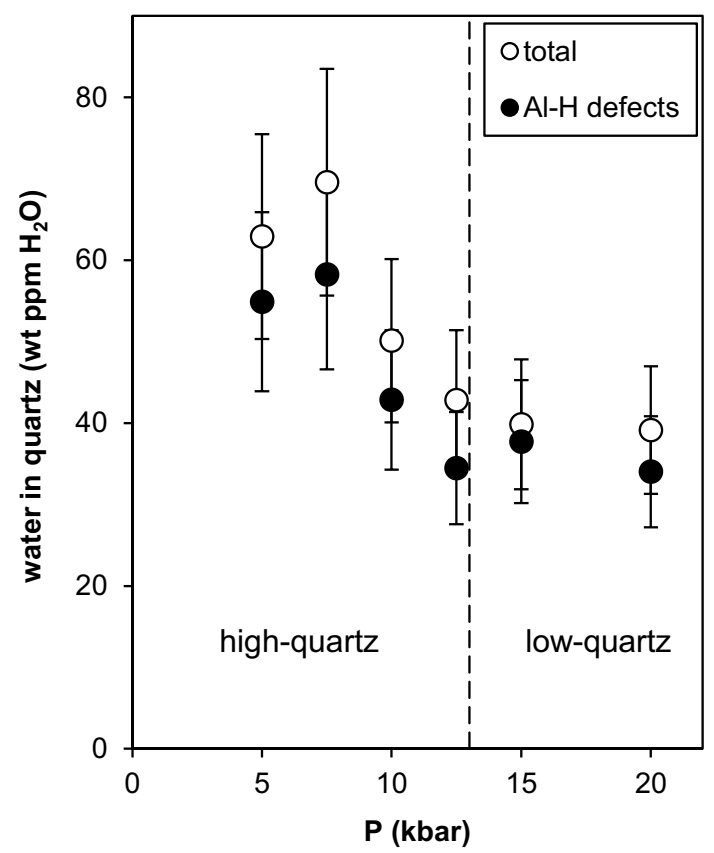

Fig. 5 Water concentrations as total amount of $\mathrm{OH}$ defects (open circles) and as Al-specific $\mathrm{OH}$ defects (black circles) from quartz grown in the $2 \%$ spodumene system. The concentrations are expressed as wt ppm water using the calibration of Libowitzky and Rossman (1997). Error bars correspond to an absolute error of $20 \%$

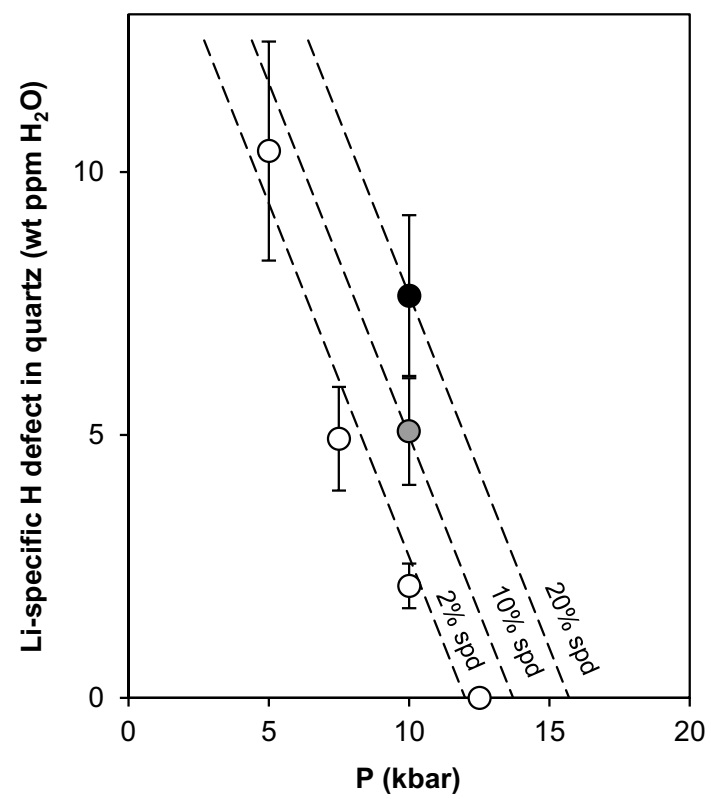

Fig. 6 Content of $\mathrm{LiOH}$ defects against pressure from quartz grown in the granitic system containing 2,10 and $20 \%$ spodumene 


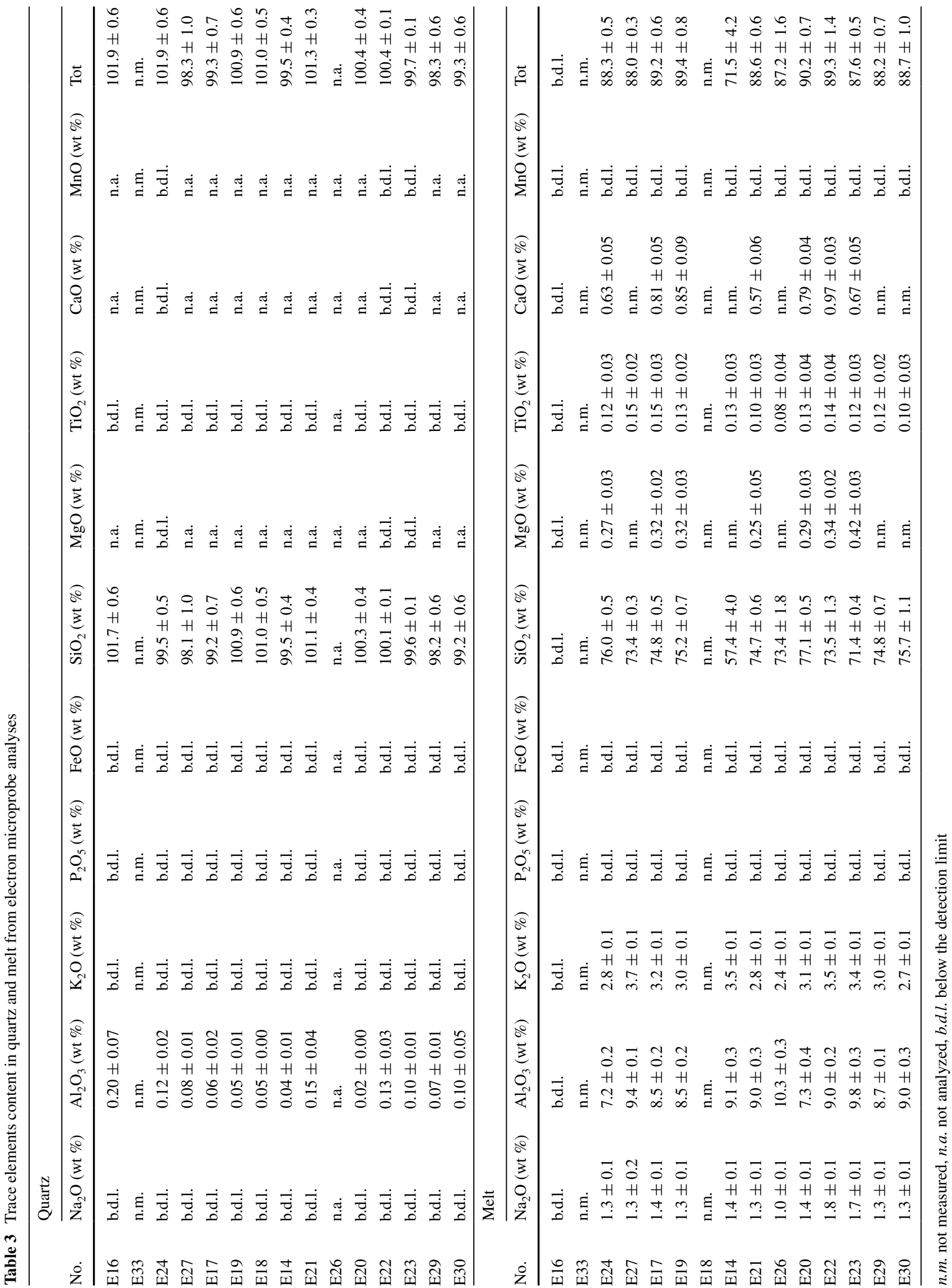


disappear even in extremely Li-rich systems at even higher pressures.

\section{Electron microprobe and LA-ICP-MS results}

Quartz, melt and accessory phases such as apatite were observed in BSE images (Fig. 1). Comparison of

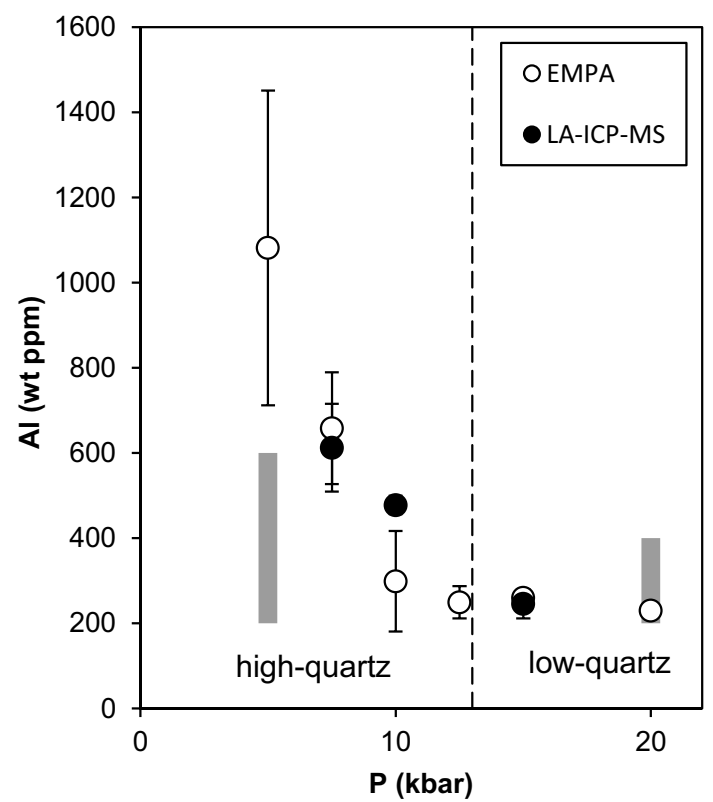

Fig. $7 \mathrm{Al}$ contents in quartz against pressure from EMPA (open circles) and LA-ICP-MS (black circles) from runs containing $2 \%$ spodumene. Areas in gray represent the results from Stalder and Konzett (2012) quantitative analyses from electron microprobe and LAICP-MS was used as tool to discriminate between measurements of inclusion-free quartz and those containing melt inclusions (see Fig. 1a). The following two criteria were interpreted as sign for melt contamination: (1) an unreasonable high concentration of $\mathrm{K}(>100 \mathrm{ppm})$, as extremely incompatible element, and/or (2) a deviation in $\mathrm{Al}$ content measured by LA-ICP-MS by more than $3 \sigma$ from the value determined by electron microprobe. Data points that showed such characteristics were considered as contaminated by tiny melt inclusions and were omitted from the data set. Data points from inclusion-free quartz and melt compositions from electron microprobe analyses are reported in Table 3. At constant temperature, $\mathrm{Al}$ in quartz shows a negative trend against pressure and decreases from $1000 \mathrm{ppm}$ at $5 \mathrm{kbar}$ to values around $250 \mathrm{ppm}$ at $20 \mathrm{kbar}$ (Fig. 7), in good agreement with the results of Stalder and Konzett (2012). The analytical totals from the measurements taken on melts are below $100 \mathrm{wt} \%$, suggesting dissolution of water in the melt. Melts that formed between 7.5 and 12.5 kbar (i.e., below the second critical endpoint) typically show analytical totals of $\sim 90 \mathrm{wt} \%$, indicating $\sim 10 \mathrm{wt} \%$ water content, whereas amorphous quench formed at $20 \mathrm{kbar}$ show analytical totals of $\sim 70 \mathrm{wt} \%$, which corresponds to $\sim 30 \mathrm{wt} \%$ water (Table 3 ).

LA-ICP-MS analytical results are reported in Table 4. Quartz crystals from some runs could not be analyzed, either because the grain size was too small to perform analyses on inclusion-free spots either due to the explosion of the sample caused by the overheating of fluid inclusions beneath the measured surface during laser irradiation.
Table 4 LA-ICP-MS measurements

\begin{tabular}{|c|c|c|c|c|c|c|}
\hline & \multicolumn{5}{|c|}{ LA-ICP-MS quartz } & \multirow{2}{*}{$\begin{array}{l}\text { LA-ICP-MS melt } \\
\mathrm{Al} / \mathrm{Li}\end{array}$} \\
\hline & $\mathrm{Li}$ (wt ppm) & B (wt ppm) & $\mathrm{Al}$ (wt ppm) & $\mathrm{P}(\mathrm{wt} \mathrm{ppm})$ & $\mathrm{K}$ (wt ppm) & \\
\hline E16 & n.a. & n.a. & n.a. & n.a. & n.a. & n.a. \\
\hline E33 & n.a. & n.a. & n.a. & n.a. & n.a. & n.a. \\
\hline E24 & $64 \pm 7$ & $4 \pm 0.2$ & $612 \pm 103$ & $16 \pm 3$ & $2 \pm 0.8$ & $65 \pm 47$ \\
\hline E27 & n.a. & n.a. & n.a. & n.a. & n.a. & 90 \\
\hline E17 & $49 \pm 2$ & $3 \pm 0.2$ & $478 \pm 22$ & $11 \pm 3$ & $<0.83 \pm 0.3$ & $35 \pm 18$ \\
\hline E20 & n.a. & n.a. & n.a. & n.a. & n.a. & $1334 \pm 221$ \\
\hline E21 & $194 \pm 37$ & $2 \pm 1$ & $1080 \pm 291$ & $10 \pm 10$ & $8 \pm 2$ & $16 \pm 1$ \\
\hline E22 & $2 \pm 0.4$ & $2 \pm 0.1$ & $196 \pm 13$ & $17 \pm 3$ & $<1.15 \pm 0.1$ & n.a. \\
\hline E23 & $3 \pm 0.1$ & $11 \pm 0.3$ & $557 \pm 16$ & $13 \pm 4$ & $<0.77 \pm 0.0$ & $621 \pm 374$ \\
\hline E26 & $337 \pm 5$ & $2 \pm 0.1$ & $1630 \pm 33$ & $12 \pm 2$ & $15 \pm 0.0$ & $6 \pm 1$ \\
\hline E29 & $2 \pm 0.2$ & $8 \pm 1$ & $425 \pm 52$ & $13 \pm 1$ & $<0.77 \pm 0.0$ & n.a. \\
\hline E30 & $81 \pm 4$ & $1 \pm 0.2$ & $451 \pm 27$ & $12 \pm 3$ & $<0.74 \pm 0.3$ & $9 \pm 0.3$ \\
\hline E19 & n.a. & n.a. & n.a. & n.a. & n.a. & $44 \pm 8$ \\
\hline E18 & $18 \pm 2$ & $2 \pm 0.1$ & $246 \pm 34$ & $15 \pm 3$ & $5 \pm 8$ & $32 \pm 18$ \\
\hline E14 & n.a. & n.a. & n.a. & n.a. & n.a. & n.a. \\
\hline
\end{tabular}

n.a. not analyzed 
LA-ICP-MS data points from the quench material exhibit a very high standard deviation, which in some cases was even higher than the mean value. However, the ratio Al/ $\mathrm{Li}$ within one sample was nearly constant, and therefore, results from the quench material are reported as $\mathrm{Al} / \mathrm{Li}$ ratio.

\section{Discussion}

\section{Li saturation}

Based on the observation of Li-specific $\left(3483 \mathrm{~cm}^{-1}\right)$ and Al-specific $\left(3379 \mathrm{~cm}^{-1}\right) \mathrm{OH}$ bands, different $\mathrm{OH}$ environments exist. The linear correlation of $\mathrm{Li}$-specific $\mathrm{OH}$ and spodumene content in the starting material observed at $10 \mathrm{kbar}$ (Fig. 4) suggests that the system is not saturated with respect to $\mathrm{Li}$ even at highest $\mathrm{Li}$ content investigated at $10 \mathrm{kbar}$. If spodumene is added to undoped granite up to $10 \mathrm{wt} \%$ spodumene in the starting material, the resulting quartz increases its $\mathrm{Li}$-specific $\mathrm{OH}$ without changing the Al-specific OH significantly (Fig. 8). Further input of spodumene leads to a further increase in $\mathrm{Li}$ specific $\mathrm{OH}$ accompanied with a decrease of $\mathrm{Al}$-specific $\mathrm{OH}$. This leads to the conclusion that $\mathrm{Li}$ is incorporated in different local environments, one of which increasing the total $\mathrm{OH}$ (presumably as $\mathrm{LiOH}$ ) and the other

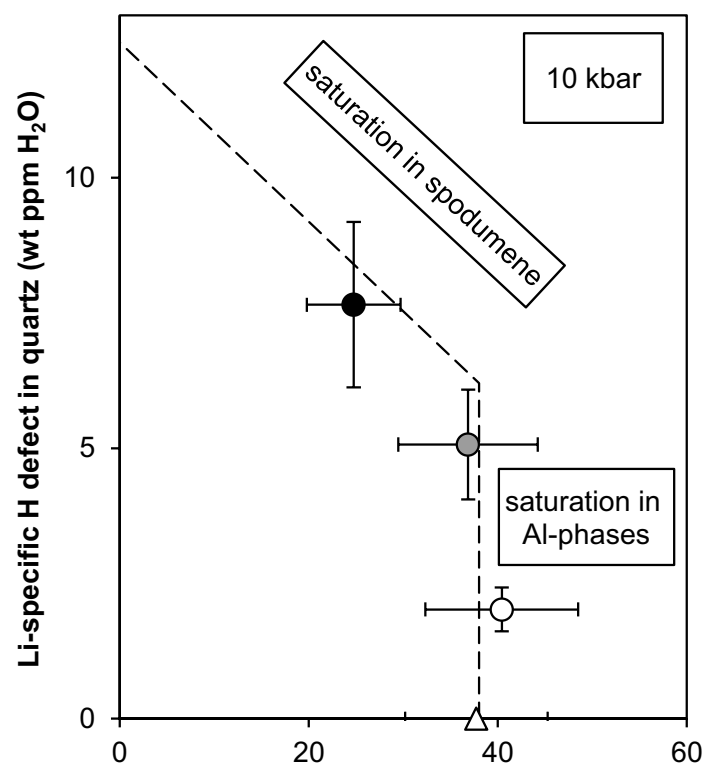

Al-specific $\mathrm{H}$ defect in quartz (wt ppm $\mathrm{H}_{2} \mathrm{O}$ )

\begin{tabular}{|ll|}
\hline$\Delta 0 \%$ spodumene & $\circ 2 \%$ spodumene \\
$\circ 10 \%$ spodumene & $\bullet 20 \%$ spodumene \\
\hline
\end{tabular}

Fig. 8 Relation of $\mathrm{LiOH}$ defect and $\mathrm{AlOH}$ defect concentrations in quartz at $10 \mathrm{kbar}$. The kink in the trend suggests a change in the saturation regime (see text for discussion) counteracting $\mathrm{OH}$ incorporation by combining with $\mathrm{Al}$ $\left(\mathrm{Si}^{4+}=\mathrm{Al}^{3+}+\mathrm{Li}^{+}\right)$and reducing the coupling capacity of $\mathrm{Al}$ to protons $\left(\mathrm{Si}^{4+}=\mathrm{Al}^{3+}+\mathrm{H}^{+}\right)$. The kink in the $\mathrm{LiOH}-\mathrm{AlOH}-$ plot may further suggest that saturation with respect to Li was reached (see dotted line in Fig. 4).

\section{Charge balance involving $\mathrm{H}$ and other impurities}

According to previous studies charge balance of impurities in quartz is achieved by $\mathrm{H}^{+}+\mathrm{A}^{+}+\mathrm{P}^{5+}=\mathrm{M}^{3+}+\mathrm{B}^{3+}$, with $\mathrm{A}=$ alkali ions and $\mathrm{M}=$ metal ions (Müller and KochMüller 2009; Baron et al. 2015). In order to account for the contrasting role of $\mathrm{Li}$, two different species for $\mathrm{Li}$ have to be defined: (I) $\mathrm{Li}_{\mathrm{I}}$ decreasing the $\mathrm{OH}$ content by forming a dry AlLi defect, and (II) $\mathrm{Li}_{\mathrm{II}}$ increasing the $\mathrm{OH}$ content by incorporation of $\mathrm{LiOH}$ and formation of non-bridging oxygens (Kats 1961). Li $\mathrm{i}_{\mathrm{II}}$ was calculated from the absorption band in the IR spectrum, and $\mathrm{Li}_{\mathrm{I}}$ was calculated by subtracting $\mathrm{Li}_{\mathrm{II}}$ from total Li determined by LA-ICP-MS. Data points show a linear correlation (Fig. 9), but deviate systematically by some $15 \%$ toward the trivalent cations. The reason for this mismatch is unknown. A major contribution of incorrect $\mathrm{Li}$ assignment is excluded due to the rather low $\mathrm{Li}$ concentrations. A better explanation is the accuracy of the IR calibration for the quantification of water contents.

\section{Pressure effect}

IR spectra of $\mathrm{OH}$ defects in quartz show systematic variations with pressure and the Li-specific band at $3483 \mathrm{~cm}^{-1}$ is reduced with increasing pressure at a given

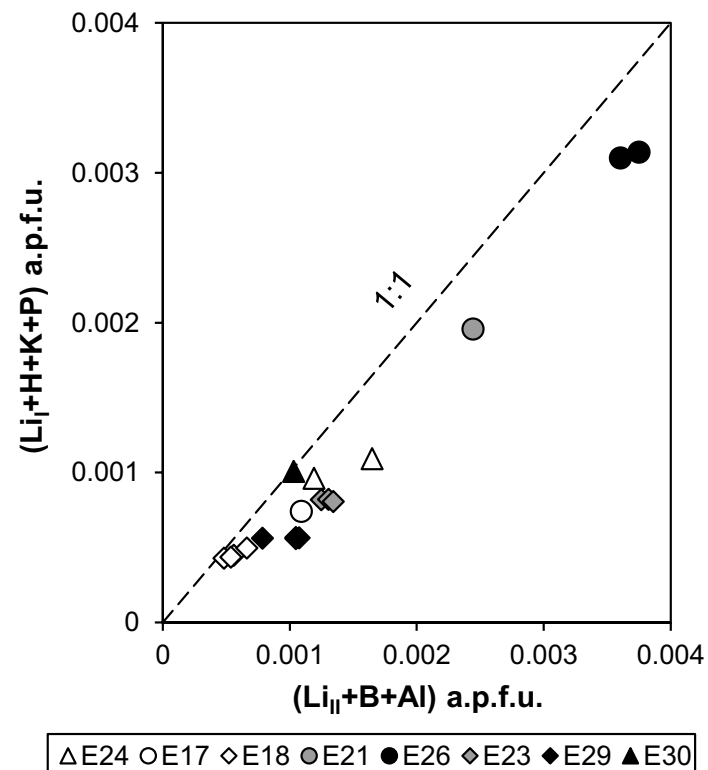

Fig. 9 Coupled substitutions of $\mathrm{H}^{+}, \mathrm{Li}^{+}, \mathrm{K}^{+}, \mathrm{Al}^{3+}, \mathrm{P}^{5+}$ and $\mathrm{B}^{3+} \cdot \mathrm{Li}_{\mathrm{I}}$ corresponds to AlLi defects and $\mathrm{Li}_{\text {II }}$ to $\mathrm{LiOH}$ defects 
Table 5 Chemistry of quartz and melt, partition coefficients $\mathrm{D}_{\mathrm{Li}}^{\mathrm{qz} / m e l t}, \mathrm{D}_{\mathrm{Al}}^{\mathrm{qz} / \text { melt }}$ and $\mathrm{D}_{\mathrm{Li}}^{\mathrm{qz} / \mathrm{melt}}, \mathrm{K}$ and $\mathrm{Al}$ content in starting material and degree of melting

\begin{tabular}{|c|c|c|c|c|c|c|c|c|c|c|c|c|c|c|c|}
\hline \multirow[t]{2}{*}{ \# Run } & \multicolumn{3}{|c|}{ Quartz (wt ppm) } & \multicolumn{4}{|c|}{ Melt (wt \%) } & \multicolumn{3}{|c|}{ Partition coefficient $\mathrm{t}^{\mathrm{q} / \text { melt }}$} & \multicolumn{2}{|c|}{$\begin{array}{l}\text { Starting mate- } \\
\text { rial }\end{array}$} & \multicolumn{3}{|c|}{ Degree of melting (\%) } \\
\hline & $\begin{array}{l}\mathrm{Li}^{\mathrm{a}} \\
(\mathrm{ppm})\end{array}$ & $\begin{array}{l}\mathrm{Al}^{\mathrm{b}} \\
(\mathrm{ppm})\end{array}$ & $\begin{array}{l}\mathrm{H}_{2} \mathrm{O}^{\mathrm{c}} \\
(\mathrm{ppm})\end{array}$ & $\begin{array}{l}\mathrm{Li}_{2} \mathrm{O}^{\mathrm{d}} \\
(\mathrm{wt} \%)\end{array}$ & $\begin{array}{l}\mathrm{K}_{2} \mathrm{O}^{\mathrm{b}} \\
(\mathrm{wt} \% \text { ) }\end{array}$ & $\begin{array}{l}\mathrm{Al}_{2} \mathrm{O}_{3}^{\mathrm{b}} \\
(\mathrm{wt} \%)\end{array}$ & $\begin{array}{l}\mathrm{H}_{2} \mathrm{O}^{\mathrm{d}} \\
(\mathrm{wt} \%)\end{array}$ & $\mathrm{D}_{\mathrm{Li}}^{\mathrm{qz} / \mathrm{melt}}$ & $\mathrm{D}_{\mathrm{Al}}^{\mathrm{qz} / \mathrm{melt}}$ & $\mathrm{D}_{\mathrm{H}}^{\mathrm{qz} / \text { melt }}$ & $\begin{array}{l}\mathrm{K}_{2} \mathrm{O} \\
\text { (wt } \% \text { ) }\end{array}$ & $\begin{array}{l}\mathrm{Al}_{2} \mathrm{O}_{3} \\
(\mathrm{wt} \%)\end{array}$ & $\mathrm{K}_{2} \mathrm{O}$ & $\mathrm{Al}_{2} \mathrm{O}_{3}$ & Average \\
\hline E16 & - & - & - & - & - & - & - & - & - & - & - & - & - & - & - \\
\hline E33 & - & - & - & - & - & - & - & - & - & - & 2 & 8 & - & - & - \\
\hline E24 & 64 & 659 & 72 & 0.2 & 3 & 7 & 12 & 0.089 & 0.017 & 0.0006 & 3 & 7 & 92 & 94 & 93 \\
\hline E27 & - & 396 & 67 & - & 4 & 9 & 12 & - & 0.008 & 0.0006 & 3 & 7 & 69 & 70 & 70 \\
\hline E17 & 49 & 299 & 50 & 0.2 & 3 & 8 & 11 & 0.058 & 0.007 & 0.0005 & 3 & 7 & 80 & 83 & 82 \\
\hline E19 & - & 250 & 43 & - & 3 & 8 & 11 & - & 0.006 & 0.0004 & 2 & 6 & 73 & 81 & 77 \\
\hline E18 & 18 & 260 & 40 & - & - & - & - & - & - & - & 2 & 6 & - & - & - \\
\hline E14 & - & 230 & 39 & - & 3 & 9 & 29 & - & 0.005 & 0.0001 & 2 & 6 & 65 & 67 & 66 \\
\hline E21 & 194 & 786 & 45 & 0.8 & 3 & 9 & 11 & 0.052 & 0.017 & 0.0004 & 2 & 7 & 81 & 78 & 79 \\
\hline E26 & 337 & $1630^{\mathrm{a}}$ & 36 & 1.5 & 2 & 10 & 13 & 0.050 & 0.030 & 0.0003 & 2 & 9 & 80 & 80 & 80 \\
\hline E20 & - & 122 & 41 & - & 3 & 7 & 10 & - & 0.003 & 0.0004 & 2 & 6 & 79 & 81 & 80 \\
\hline E22 & 2 & 691 & 54 & 0.0 & 4 & 9 & 11 & - & 0.015 & 0.0005 & 2 & 5 & 60 & 66 & 63 \\
\hline E23 & 3 & 538 & 115 & 0.0 & 3 & 10 & 12 & - & 0.010 & 0.0009 & 2 & 7 & 67 & 68 & 67 \\
\hline E29 & 2 & 361 & 78 & 0.0 & 3 & 9 & 12 & - & 0.008 & 0.0007 & 2 & 6 & 72 & 74 & 73 \\
\hline E30 & 81 & 542 & 47 & 0.8 & 3 & 9 & 11 & 0.022 & 0.011 & 0.0004 & 2 & 7 & 76 & 77 & 77 \\
\hline
\end{tabular}

starting composition. If we consider endmember compositions for coupled substitutions such as $\mathrm{HAlO}_{2}$ (for $\mathrm{Si}^{4+}=\mathrm{Al}^{3+}+\mathrm{H}^{+}$) and $\mathrm{LiAlO}_{2}\left(\right.$ for $\mathrm{Si}^{4+}=\mathrm{Al}^{3+}+\mathrm{Li}^{+}$), increasing pressure shifts the reaction

$\mathrm{HAlO}_{2}+\mathrm{LiOH}=\mathrm{LiAlO}_{2}+\mathrm{H}_{2} \mathrm{O}$

or

$2 \mathrm{SiO}_{2}+\mathrm{HAlO}_{2}+\mathrm{LiOH}=\mathrm{LiAlSi}_{2} \mathrm{O}_{6}+\mathrm{H}_{2} \mathrm{O}$

to the right and in this way reduces the total amount of $\mathrm{OH}$ defects. Based on the present results most of the shift in the reaction seems to occur at a rather narrow pressure interval, namely between 10 and $15 \mathrm{kbar}$. In this pressure interval falls the transition from high-quartz to low-quartz (Mirwald and Massonne 1980). If the high-/low-quartz transition were relevant for the preferred incorporation of $\mathrm{LiAl}$ defects, we would expect lower LiAl defects at high pressure, because $\mathrm{LiAlSi}_{2} \mathrm{O}_{6}$ can crystallize in high-quartz structure (London 1984), which is stable below $13 \mathrm{kbar}$. However, according to reaction (1a) and (1b), the LiAl component is better incorporated above $13 \mathrm{kbar}$, which makes a connection of this hypothesis and the high-/lowquartz transition questionable. On the other hand, as far as total concentrations of $\mathrm{Li}$ and $\mathrm{Al}$ are concerned, the negative correlation to pressure (Fig. 7) seems to be in accord to the preferred LiAl coupling in the high-quartz field (i.e., at low pressure). The appearance of a dominant $\mathrm{LiOH}$ absorption band at $3483 \mathrm{~cm}^{-1}$ seems to be related to quartz that crystallized at rather low pressures. Samples from nature with these characteristics exist, such as large hydrothermal quartz crystals that grew in the roof region of late stage magmatic systems and show a high $\mathrm{LiOH} / \mathrm{AlOH}$ band ratio, e.g., the rock crystal from Brazil reported in Stalder and Neuser (2013).

\section{Partitioning of $\mathrm{Al}, \mathrm{Li}$ and $\mathrm{H}$ between quartz and melt}

Since concentrations of $\mathrm{Li}$ in the melt could not be measured directly, Li concentrations in the quenched melt were calculated by mass balance. In order to do this, in a first step melt fractions were calculated from $\mathrm{K}_{2} \mathrm{O}$ and $\mathrm{Al}_{2} \mathrm{O}_{3}$ content in the melt (the only significant repository of these elements). Furthermore, it was assumed that only insignificant amounts of Li are dissolved in the excess fluid after the experiment, because the $\mathrm{pH}$ of the fluid phase was close to neutral. Consequently, also $\mathrm{Li}$ was considered to be hosted mainly in the melt, and its concentrations were calculated based on the melt fraction calculated before. Hydrogen 
concentrations in the melts were calculated by subtracting the electron microprobe's analytical totals from $100 \%$. Concentrations were used to determine partition coefficients for $\mathrm{Al}, \mathrm{Li}$ and $\mathrm{H}$ between quartz and melt, which follow the order $\mathrm{D}_{\mathrm{Li}}^{\mathrm{qz} / \mathrm{melt}}>\mathrm{D}_{\mathrm{Al}}^{\mathrm{qz} / \mathrm{melt}}>\mathrm{D}_{\mathrm{H}}^{\mathrm{qz} / \text { melt }}$ (Table 5). At 10 kbar, three different correlations are observed between the Log of $\mathrm{D}_{\mathrm{Li}}^{\mathrm{qz} / m e l t}, \mathrm{D}_{\mathrm{Al}}^{\mathrm{qz} / \mathrm{melt}}, \mathrm{D}_{\mathrm{H}}^{\mathrm{qz} / \text { melt }}$ and the spodumene content in the starting material (Fig. 10), that is (1) an almost horizontal trend for $\mathrm{Li}$, (2) a clear positive trend for $\mathrm{Al}$ and (3) a slightly negative trend for $\mathrm{H}$. In particular, the trends for $\mathrm{D}_{\mathrm{Li}}^{\mathrm{q} z / \text { melt }}$ and $\mathrm{D}_{\mathrm{Al}}^{\mathrm{q} z}$ melt converge at $20 \mathrm{wt} \%$ spodumene and a kink for $\mathrm{D}_{\mathrm{Al}}^{\mathrm{qz} / \mathrm{melt}}$ between 10 and $15 \mathrm{wt} \%$ of spodumene content in the starting material is observed. The convergence and the kink might confirm the hypothesis that the system is saturated in spodumene for these conditions. Pressure does also affect the partitioning of $\mathrm{Li}, \mathrm{Al}$ and $\mathrm{H}$ between quartz and melt. Experiments performed on starting material containing $2 \mathrm{wt} \%$ spodumene at pressures between 5 and $20 \mathrm{kbar}$, show in fact a negative correlation between the Log of $\mathrm{D}_{\mathrm{Li}}^{\mathrm{qz} / \mathrm{melt}}, \mathrm{D}_{\mathrm{Al}}^{\mathrm{qz} / \mathrm{melt}}, \mathrm{D}_{\mathrm{H}}^{\mathrm{qz} / \text { melt }}$ and pressure (Fig. 11). All the trends present the same inclination, suggesting that $\mathrm{Li}, \mathrm{Al}$ and $\mathrm{H}$ incorporations are related.

\section{The effect of apatite on defects incorporation in quartz}

In this study it is observed that the presence of apatite in the bulk system has only a weak effect on the intensities of $\mathrm{OH}$

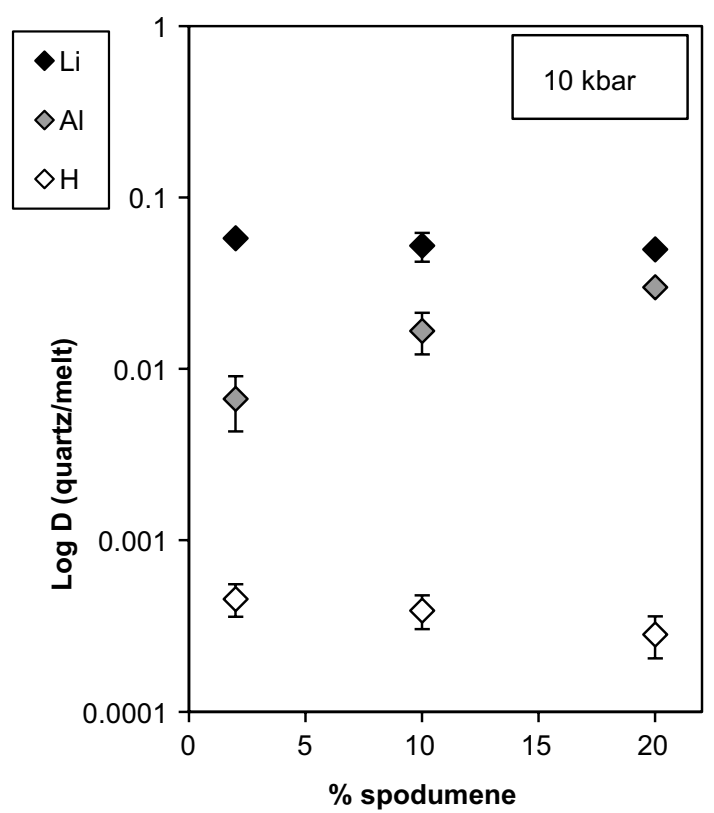

Fig. 10 Relations between the Log D(quartz/melt) of $\mathrm{Li}, \mathrm{Al}, \mathrm{H}$ and spodumene concentration in the starting material for experiments performed at $10 \mathrm{kbar}$. $\mathrm{D}_{\mathrm{Al}}^{\text {quartz/melt }}$ shows a positive trend that kinks between 10 and $20 \mathrm{wt} \%$ spodumene and converges with $\mathrm{D}_{\mathrm{Li}}^{\text {quartz/melt }}$ at $20 \mathrm{wt} \%$ spodumene. These particular features might confirm the hypothesis of a change in the saturation regime

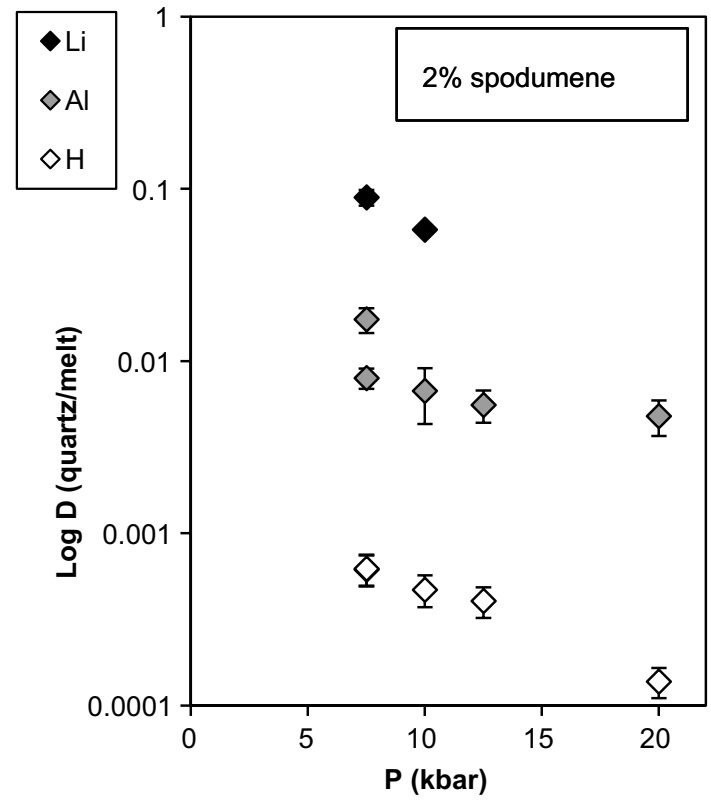

Fig. 11 Relations between the Log $\mathrm{D}$ (quartz/melt) of $\mathrm{Li}, \mathrm{Al}, \mathrm{H}$ and pressure for experiments performed with starting materials containing $2 \mathrm{wt} \%$ spodumene. All the trends show the same negative inclination

bands. LA-ICP-MS measurements revealed constant concentrations of 10-17 ppm $\mathrm{P}$ in quartz for all run products, suggesting that even the undoped system was saturated by apatite, even if it was only observed in BSE images at higher concentration levels (Fig. 1c). A weak coupling of $\mathrm{P}^{5+}$ to $\mathrm{B}^{3+}$ and $\mathrm{Al}^{3+}$ is possible, as apatite slightly reduces the $\mathrm{AlOH}$ and $\mathrm{BOH}$ bands in when added to the tourmaline-doped system (Fig. 3). High concentrations of P in the starting material may further influence phase and melting relation and therefore indirectly affect the trace elements incorporation (including $\mathrm{OH}$ defects) in quartz.

Compared to quartz from natural samples, phosphorous in quartz is well within the reported range for $\mathrm{P}_{2} \mathrm{O}_{5}$ enriched granites and monazite-bearing pegmatites that contain 7-10 ppm P (Breiter and Müller 2009) and 9-23 ppm P (Larsen et al. 2004), respectively.

Acknowledgments Open access funding were provided by University of Innsbruck and Medical University of Innsbruck. We like to thank Hannes Witting for manufacturing the high-pressure assemblies and Philipp Mair for helping in performing high-pressure experiments E16 and E33. Many thanks also to Richard Tessadri for XRF analysis on the starting material, Martina Tribus for the calibration of the electron microprobe and Daniela Schmidmair for XRD analysis.

Open Access This article is distributed under the terms of the Creative Commons Attribution 4.0 International License (http://creativecommons.org/licenses/by/4.0/), which permits unrestricted use, distribution, and reproduction in any medium, provided you give appropriate credit to the original author(s) and the source, provide a link to the Creative Commons license, and indicate if changes were made. 


\section{References}

Aines RD, Rossman GR (1984) Water in minerals? A peak in the infrared. J Geophys Res 89:4059-4071

Aines RD, Kirby SH, Rossman GR (1984) Hydrogen speciation in synthetic quartz. Phys Chem Miner 11:204-212

Bambauer HU (1963) Merkmale des OH-Spektrums alpiner Quarze

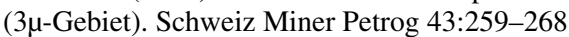

Baron MA, Stalder R, Hauzenberger CA (2015) OH-point defects in quartz in B- and Li-bearing systems and their application to pegmatites. Phys Chem Miner 42:53-62

Breiter K, Müller A (2009) Evolution of rare-metal granitic magmas documented by quartz chemistry. Eur J Mineral 21:335-346

Chakraborty D, Lehmann G (1976) Distribution of OH in synthetic and natural quartz crystals. J Solid State Chem 17:305-311

Dennen WH, Blackburn WH, Quesada A (1970) Aluminium in quartz as a geobarometer. Contrib Mineral Petrol 27:332-342

Guillong M, Meier DL, Allan MM, Heinrich CA, Yardley BWD (2008) SILLS: a matlab-based program for the reduction of laser ablation ICP-MS data of homogeneous materials and inclusions. Mineral Assoc Canada Short Course 40:328-333

Huang R, Audétat A (2012) The titanium-in-quartz (TitaniQ) thermobarometer: a critical examination and re-calibration. Geochim Cosmochim Acta 84:75-89

Jochum KP, Weis U, Stoll B, Kuzmin D, Yang Q, Raczek I, Jacob DE, Stracke A, Birbaum K, Frick DA, Günther D, Enzweiler J (2011) Determination of reference values for NIST SRM 610 617 glasses following ISO guidelines. Geostand Geoanal Res 35:397-429

Kats A (1961) Hydrogen in alpha quartz. Dissertation, Delft University of Technology, Netherland

Kats A (1962) Hydrogen in alpha quartz. Philips Res Rep 17:133-279

Larsen RB, Henderson I, Ihlen PM, Jacamon F (2004) Distribution and petrogenetic behavior of trace elements in granitic pegmatite quartz from South Norway. Contrib Mineral Petrol 147:615-628

Libowitzky E, Rossman GR (1997) An IR calibration for water in minerals. Am Mineral 82:1111-1115

London D (1984) Experimental phase equilibria in the system LiAl$\mathrm{SiO}_{4}-\mathrm{SiO}_{2}-\mathrm{H}_{2} \mathrm{O}$ : a petrogenetic grid for lithium-rich pegmatites. Am Mineral 69:995-1004

Matter A, Ramseyer K (1985) Cathodoluminescence microscopy as a tool for provenance studies of sandstones. NATO ASI Series 148:191-211
Mirwald PW, Massonne HJ (1980) The low-high quartz and quartzcoesite transition to $40 \mathrm{kbar}$ between $600{ }^{\circ} \mathrm{C}$ and $1600{ }^{\circ} \mathrm{C}$ and some reconnaissance data on the effect of $\mathrm{NaAlO} 2$ component on the low quartz-coesite transition. J Geophys Res 85:6983-6990

Müller A, Koch-Müller M (2009) Hydrogen speciation and trace element contents of igneous, hydrothermal and metamorphic quartz from Norway. Mineral Mag 73:569-583

Müller A, Wiedenbeck M, Van den Kerkhof AM, Kronz A, Simon K (2003) Trace elements in quartz: a combined electron microprobe, secondary ion mass spectrometry, laser-ablation ICP-MS and cathodoluminescence study. Eur J Mineral 15:747-763

Paterson MS (1986) The thermodynamics of water in quartz. Phys Chem Miner 13:245-255

Richter DK, Götte T, Götze J, Neuser RD (2003) Progress and application of cathodoluminescence (CL) in sedimentary petrology. Miner Petrol 79:127-166

Rovetta MR (1989) Experimental and spectroscopic constraints on the solubility of hydroxyl in quartz. Phys Earth Planet In 55:326-334

Stalder R, Konzett J (2012) OH-defects in quartz in the system quartz-albite-water and granite water between 5 and 25 kbar. Phys Chem Miner 39:817-827

Stalder R, Neuser RD (2013) OH-defects in detrital quartz grains: potential for application as tool for provenance analysis and overview over crustal average. Sediment Geol 294:118-126

Thomas SM, Koch-Müller M, Reichart P, Rhede D, Thomas R, Wirth $\mathrm{R}$ (2009) IR calibrations for water determination in olivine, r- $-\mathrm{GeO}_{2}$ and $\mathrm{SiO}_{2}$ polymorphs. Phys Chem Miner 36:489-509

Thomas JB, Watson EB, Spear FS, Shemella PT, Nayak SK, Lanzirotti A (2010) TitaniQ under pressure: the effect of pressure and temperature on the solubility of $\mathrm{Ti}$ in quartz. Contrib Mineral Petrol 160:743-759

Truckenbrodt J, Ziegenbein D, Johannes W (1997) Redox conditions in piston-cylinder apparatus: the different behavior of boron nitride and unfired pyrophyllite assemblies. Am Mineral 82:337-344

Wark DA, Watson EB (2006) TitaniQ: a titanium-in-quartz geothermometer. Contrib Mineral Petrol 152:743-754

Zinkernagel U (1978) Cathodoluminescence of quartz and its application to sandstone petrology. Contrib Sediment Geol 8:1-69 